\title{
Moving beyond confessional theologies and secular philosophies about the world: Towards an ecodomic public attitude about nature
}

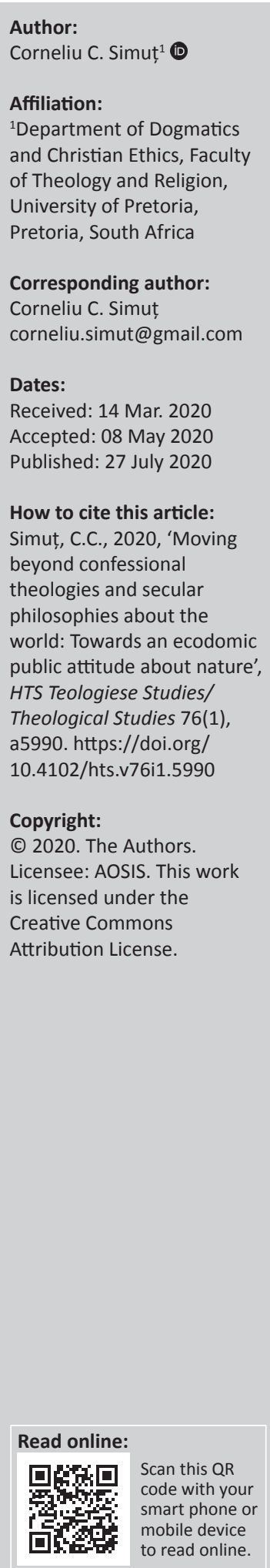

This article is firstly an investigation of traditional Christian thought about the world with the purpose of establishing whether Christianity's three main confessions (Eastern Orthodoxy, Roman Catholicism and mainline Protestantism) share similar concerns about the current situation of nature. Secondly, the investigation is followed by a comparison between the common features of these three confessional theologies and similar patterns of thought in the secular world, with the intention of finding ecological issues that are common not only to the three confessional theologies but also to secular philosophies. Thirdly, the initial investigation of Christianity's three main confessional theologies, followed by the comparison between these confessional theologies and secular philosophies of nature, is completed by the concrete proposal that, in order for contemporary ecological issues to be met with viable solutions, a common public attitude about nature, which goes beyond confessional theologies and secular philosophies, needs to be pursued globally in an ecodomic (constructive and edifying) manner.

Contribution: Despite the numerous theories about concrete ways to improve the current state of nature, this article is an attempt to go a step beyond the established theological and philosophical perspectives on the world towards a constructive public attitude which is meant to be characterised by the real possibility of immediate action.

Keywords: Ecodomy; Public theology; Confessional theology; Secular philosophy; The Earth Charter; Accra Confession; Ecology; Nature.

\section{Introduction}

Leaving aside their doctrinal and historical aspects, Christian confessions have professed the same belief in God as creator of the cosmos and life. In their capacity as branches of Christianity, Eastern Orthodoxy, Roman Catholicism and mainline Protestantism have traditionally taught that nature is the result of God's creation [creation passiva] - a God whose existence is ontologically real, personal and liberating for the salvation of human beings and the entire creation. This article is an attempt to see whether a common ground about the improvement of the current state of nature can be found not only within the theological thought of Eastern Orthodoxy, Roman Catholicism and mainline Protestantism (which I called 'confessional theologies') but also beyond them into the philosophical thinking of secular people (which I dubbed 'secular philosophies'). At the same time, the article investigates the possibility of moving beyond both these categories into something which allows the main concerns of each to co-exist in a longlasting solution.

Methodologically, I shall investigate theological examples which are representative of the three main Christian traditions: the 1989 message of Ecumenical Patriarch Dimitrios for Eastern Orthodoxy, the 2015 Laudato Si' encyclical letter of Pope Francis for Roman Catholicism and the 2006 Christianity and Ecological Theology, a book written by Ernst Conradie, a South African theologian whose varied interests in the relationship between theology and nature can be considered characteristic of mainline Protestantism. Provided that common ground is indeed found between these three confessional traditions, an inquiry will be made into the possibility of merging confessional theologies (or traditional Christian views) and secular philosophies (or non-Christian, even non-religious thinking) about nature. In this respect, a comparison will be made between the 2004 'Accra Confession' of the then World Alliance of Reformed Churches (seen as typical for all three confessional theologies) and the 2000 'Earth Charter', a non-religious ethical document which is standard for secular thinking.

Note: Special Collection entitled Theology and Nature, sub-edited by Johan Buitendag (UP) 
At the same time, if the three confessional theologies on the one hand and secular philosophies on the other hand have a common ground in how they see nature and the solutions to improve its current status, it will be argued that both must be simultaneously ecodomic (or environmental constructive) and public in their dealings with ecological issues. The idea of ecodomy is derived from Müller-Fahrenholz's (1995:109) definition, which presents ecodomy as 'the art of inhabiting instead of dominating the earth, our house' but 'can be extended to any constructive process'. Along these lines, in 2014, the notion of ecodomy was introduced by Johan Buitendag, the then dean of the Faculty of Theology at the University of Pretoria, as the main research theme of the Faculty, with a focus on stewardship (of creation) by integrating all aspects of private and public life, including ecology (Buitendag 2019:6). Thus, it will be established if not only the three main Christian and confessional theologies but also their secular counterparts can be said to be ecodomic or constructive, as well as publicly oriented in finding ecological solutions to the current state of nature despite their traditional opposition. If this inquiry produces positive results, then it will be argued that an ecodomic public attitude about nature which transcends both confessional theologies and secular philosophies is a genuine possibility for the advancement of critical thinking and concrete action regarding the improvement of environmental parameters starting from the classic relationship between theology and nature.

\section{Theology and nature in Eastern Orthodoxy}

A key document which confirms the concern expressed by Eastern Orthodoxy regarding the state of the environment in contemporary times is the message provided by the very Ecumenical Patriarch Dimitrios in 1989. Thus, the chief ecclesiastical officer of the Eastern Orthodox Church underlines that nature is being affected by humans to such an extent that the continued existence of the world is seriously called into question. The matter is so serious that, as confirmed by Kerber (2020:352), Dimitrios 'declared 01 September of each year, the first day of the ecclesiastical year in the Orthodox Church, to be the day of the protection of the natural environment'. The patriarch's words are quite revealing in this respect when he states that his office (Dimitrios 1989):

$[W]$ ith great anxiety follows the merciless trampling down and destruction of the natural environment which is caused by man with extremely perilous consequences for the very survival of the natural world created by God. (n.p.)

Harsh as they are, these words are not singular. As such, the patriarch charges his fellow human beings with 'abuse', 'apocalyptic self-destruction', 'natural pollution' and 'extinction of many special' of plants and animals, all of which lead to 'threatening' results for life on Earth (Dimitrios 1989). He also indicates that the scientific world has already taken note of this disastrous situation which caused the 'phenomenon of the greenhouse', a meteorological scenario believed by the patriarch to have already settled within the earth's climate (Dimitrios 1989). If there is one single idea that can be identified in the patriarch's warning, it is that of danger: nature is in danger, human beings are in danger, all living organisms are in danger, and the whole world is in danger because of human's work in the world (Dimitrios 1989).

According to Dimitrios (2019), this dire situation cannot be left unanswered by the Eastern Orthodox Church which he defines as 'the Church of Christ'. This very definition of the church foretells a dogmatic approach to whatever follows as official ecclesiastical response. Thus, the first aspect of the Eastern Orthodoxy's answer to the contemporary plight of the natural world not only reveals but also galvanises the relationship between theology and nature, 'the fundamental dogma of (the church's) faith' resides in the conviction that 'the world was created by God the Father' (Dimitrios 1989:n.p.). This essential belief that nature must be seen as God's creation is confirmed not only by the Scripture itself in its capacity as the primary source of Christianity but also by the Church Fathers, a methodology which is in line with the Eastern Orthodox Church's approach to theology in general. The Church Fathers are crucial for Dimitrios' argument because, as Nellist (2018:101) correctly notices, they are believed to provide a 'more compassionate' perspective on these issues. In this respect, Dimitrios points to the fact that in patristic theology, 'man is the prince of creation', a capacity in which he is 'endowed with the privilege of freedom'. The human being, however, is also a 'partaker of the material and the spiritual world' but, because he failed to accomplish his 'great destiny' in Adam's 'failure and fall', his very existence and the reality of creation itself were deeply affected by 'decay and death' (Dimitrios 1989). A solution was provided by God through the incarnation of his Son by uniting 'the created world' and 'the uncreated God' in the person of Jesus as seen in the Eucharist: an ongoing demonstration that creation (the bread and wine) and God (Christ's presence in the bread and wine) cannot be detached from one another (Dimitrios 1989).

In other words, precisely because God and creation cannot be separated, theology and nature are also characterised by an indestructible bond. The human being was created by God 'to have dominion over the earth', as stated in Genesis 1:28 (Dimitrios 1989), which means that men and women are supposed to be stewards of creation; they do not own creation and they do not have power over it. They do have the freedom to act upon it, but such an action is envisioned by God as characterised by 'love', 'thankfulness', 'respect' and 'reverence' to God in his capacity as the Creator (Dimitrios 1989). Nevertheless, God's initial design of creation and human beings was turned by the latter through the very agency of the divine gift of freedom - into a 'violation of nature' (Dimitrios 1989). These words are stunningly strong, and Chryssavgis (2013:154) is careful to highlight that it was 'fitting' for a patriarch who 'was known for his meekness' to raise awareness about 'the environment, which human beings have treated so harshly'. 
In Dimitrios' (2019) imagery, which reflects the theological position of the Eastern Orthodox Church, man's initial freedom fell into 'extreme rationalism' and 'selfcenteredness' which broke the intended connection between theology and nature. In concrete terms, 'the sense of sacredness of creation' disappeared from the human being's collective consciousness to the point that the human being itself became an 'arbitrary rule' and a 'rude violator' of the divine creation (Dimitrios 1989). Human's 'basic human needs' were replaced by 'desires and lust', which, in turn, transformed man's stewardship of creation into what the patriarch calls the 'prevailing philosophy of a consumer society' (Dimitrios 1989). This is to say that human's relationship with the world is dominated by unbridled exploitation, unlimited arrogance and certain 'self-destruction' because infinity is a feature of God, not of his creation (Dimitrios 1989). In other words, human's catastrophic dealings with nature cannot go on 'infinitely' (Dimitrios 1989), which means that new strategies about world economies must be explored and implemented across the world.

Are there any solutions to this fateful situation? Apparently so, because Dimitrios (2019) appears to take an ecodomic approach to provide a positive course of action when he identifies 'prayers and supplications for all creation' as a concrete solution. This ecodomical stance is not only confessional but also ecumenical because Dimitrios issues an invitation to 'the entire Christian world' to join in 'prayers and supplications' for the state of the natural world which he defines as 'the great gift of Creation' (Dimitrios 1989). In Eastern Orthodoxy, nature must be given 'protection and salvation', but this cannot be done without a common and universal effort (Dimitrios 1989). However, this ecodomic approach of the Eastern Orthodox Church cannot be successfully achieved only by the immediate theological means of 'prayers and supplications' (Dimitrios 1989). This practical aspect was also noticed by Kinnamon (2014:50) who highlighted the global character of these supplications that should be made for 'all creation'. As far as Dimitrios (2019) is concerned, theology also needs the help of education because 'the faithful' are supposed to 'admonish' their children 'to respect and protect the natural environment'. Genuine ecodomy, however, is far from being accomplished successfully if theology is joined only by education; this is why Dimitrios stated that politics is also needed for this environmental equation to be solved efficiently. So 'those who are entrusted with the responsibility of governing nations' must also be involved in the universal endeavour to keep the world safe from the harmful consequences of man's irresponsible exploitation (Dimitrios 1989). The traditional Eastern Orthodoxy 'symphony' between church and state must work in this respect as well because politicians are urged to take 'all necessary measures for the protection and preservation of natural creation' (Dimitrios 1989).

In the end, it seems that in Eastern Orthodoxy, the ecodomic approach to the relationship between theology and nature involves theology, education and politics, all amounting to what can be commonly called a solid sample of public theology - in this particular case, as perceptively noticed by Clapsis (2020:89), a public theology mediated by the Bible, liturgical life and especially the Eucharist. In the words of Kim (2011:152), the ecodomic effort 'is not only theologizing in the academy and the church but ... mobilizing wider society by using advocacy, demonstrations, and education of the general public'. An ecodomic public theology of nature is genuinely within the grasp of human beings for as long as we not only realise but also act upon doing something in moving theological teachings from churches and schools into the public square. Theology, education, economy and politics are all vitally important provided that their theoretical insights become practical realities in the life of as many communities as possible. In other words, theology, education and politics are crucially significant for the identification of viable solutions for the improvement of the natural state, but they become ecodomic only when vigorous action is taken to support theoretical work in as many fields as possible with the purpose of reaching as many people as possible and practically implementing as many solutions as possible.

\section{Theology and nature in Roman Catholicism}

The state of natural environment is of serious concern for Roman Catholicism also, as confirmed by Laudato $\mathrm{Si}^{\prime}$, one of Pope Francis' encyclical letters published in 2015. Inspired by Francis of Assisi's famous Canticle of Creatures, the letter expresses the current pope's preoccupation with the contemporary situation of the natural world as he builds his arguments on theological grounds. According to Francis of Assisi (1999:114), the world is like a sister and a mother, both sharing and caring for us despite our reckless actions that inflict pain and damage on them. Pope Francis insists that, given these alarming human actions with damaging repercussions on the natural world, human beings must learn that indifference to the world must never be condoned as a general attitude throughout societies (Francis 2015:3-4). Everything in the world should be important to as many human beings as possible to the point that humanity is united by the same concern for the improvement of the actual state of nature (Francis 2015:7). The pope launches an appeal 'to protect our common home' which is aimed at initiating 'a new dialogue about how we are shaping the future of our planet' (Francis 2015:12). Kureethadam (2019:21) explains that the pope's appeal is mandatory given that earth is not just 'our home', but 'our only home'. The current situation of earth, often defined by Pope Francis as 'our common home', is anything but good: pollution, waste and a popular philosophy dominated by a sense of disrespect for what exists in the world is frightening. This 'throwaway culture', as Pope Francis calls it, has disastrous consequences on planet Earth and especially on its climate (Francis 2015:16-18).

Taking the gravity of the situation into account, the pope highlights the mandatory character of a new awareness that must be developed by us, namely that climate is our 'common good' and it must be treated as such if improvement is to 
become an achievable reality. In the pope's words, 'changes of lifestyle, production, and consumption' need to be implemented rapidly 'in order to combat' what he calls 'the disturbing warming of the climatic system' (Francis 2015:18). Other more particular issues, such as water, the 'loss of biodiversity', the 'decline in the quality of human life', the 'breakdown of society' and 'global inequality', should also capture our attention mainly because these problems have been met only with 'weak responses' despite the 'variety of opinions' that exist amongst scientists and theologians (Francis 2015:22-44). The latter category, which Pope Francis himself is part of, must contribute at least by offering a theological perspective on nature. As such, nature must be seen as created by God, so the world is the result of an act of creation, in which case at least some responses must come through 'the light offered by faith' based on 'the wisdom of the biblical accounts' (Francis 2015:45). Rourke (2016:161) reveals that this sort of wisdom could prove beneficial to 'the political world' so that proper action is taken decisively 'by true politics oriented toward the global common good'. To briefly summarise, the pope insists that humanity must take on a different sort of philosophy because 'a spirituality which forgets God as all-powerful and Creator is not acceptable' (Francis 2015:55). In the absence of such a spirituality, human beings are convinced that they have the 'unlimited right to trample his (God's) creation underfoot' by trying 'to impose their own laws and interests on reality' (Francis 2015:55).

Accepting this spirituality of awareness, however, implies our willingness to recognise the 'mystery of the universe' and the 'harmony of creation' to the extent that we see the world and nature in all its totality as 'a universal communion' and a 'shared inheritance' (Francis 2015:56-68). In other words, we all live on Earth, we all benefit from its resources and we all breath its very same air, an awareness which must lead to an ethical perspective on nature and the world in general. Pope Francis reiterates that the natural environment is a collective good, the patrimony of all humanity, and the responsibility of everyone' (Francis 2015:70). All human beings must administer earth 'for the good of all', so the purpose of this theologically informed ecological perspective on the world is the common good. Furthermore, as no human being can claim detachment from this global responsibility, the pope's appeal becomes a clear sample of public theology based on the simple words of Jesus, whose concern for the 'flowers in the field and the birds' present natural reality is 'imbued with his radiant presence' (Francis 2015:74). According to Balabanski (2020:80), this means that Christ 'is mysteriously holding them to himself and directing them toward fulness as their end', which points to the divine purpose of all creation and all human beings, irrespective of their belief or disbelief in God. Thus, as far as Pope Francis is concerned, all human beings must become aware of the 'human roots of the ecological crisis' which lie in the faulty use of technology and the 'globalization of the technocratic paradigm' leading to 'modern anthropocentrism', a philosophy dominated by 'complete indifference' and 'practical relativism' (Francis
2015:75-86). In other words, objects become worthless and human beings become objects; we must therefore 'protect employment' and use 'new biological technologies' based on the divine worth of each human being as part of God's creation (Francis 2015:87-101).

Because Pope Francis' discourse is actively engaged in building a philosophy of life that can be suitable not only to believers but also to unbelievers, his enterprise is thoroughly ecodomic in nature. Thus, he advocates an 'integral ecology' which combines environmental, economic, social and cultural concerns so that it can lead to an 'ecology of daily life' or a general awareness regarding the world that is part of and informs our daily activities (Francis 2015:103-110). If there is one phrase which encapsulates the pope's philosophy of life, it is 'human dignity', a phrase that builds on 'the principle of the common good' (Francis 2015:115). This is, quite obviously, a public theology aimed at identifying 'lines of approach and action' through 'dialogue on the environment in the international community' (Francis 2015:121). The pope is convinced that this requires 'one world with a common plan'; otherwise, the common good informed by human dignity as divine creature would yield no concrete results. Or, in the words of Prellwitz (2017:155), 'interdependence and unity' are crucial for a successful effort for the 'enactment of an integral ecology'. Evidently, politics - good politics - plays a crucial role in this international dialogue which is supposed to positively transform 'national and local policies' in a responsible way (Francis 2015:129). The means to achieve this goal include 'transparency in decision-making' as well as placing 'politics and economy in dialogue for human fulfilment' (Francis 2015:137). In this respect, the pope's appeal is not only ecumenical (in the sense that it invites all Christians to join this global effort) but also syncretic in gathering all 'religions in dialogue with science' (Francis 2015:145). Nevertheless, theology, religion and politics cannot work without education because this responsible philosophy of life cannot be nourished without proper 'ecological education and spirituality', which includes 'a new lifestyle' based on key human sentiments such as 'joy and peace' as well as 'civic and political love' (Francis 2015:149-168).

The message of Pope Francis ends in a very Roman Catholic way which underlines the vital role of sacraments as a means to mediate 'supernatural life' within the human being's natural reality. Thus, the Eucharist, the Trinity and Mariology (the image of Mary as 'queen of all creation') become instruments that convey this ecodomic public theology anchored in proper education, efficient economy and good politics. As Roman Catholic as it is, however, the pope's appeal is not mandatorily and exclusively Roman Catholic but rather comprehensively perspectival and encompassing, in the sense that it invites all human beings, not only Catholics, to consider what lies 'beyond the sun' (and even beyond the natural universe itself) into the very realm and the actual existence of God himself (Francis 2015:176). An ecodomic public theology of nature is possible, as Sagovsky (2017:267) explains, only if 'key 
themes' such as 'human dignity, the common good, subsidiarity (support at local level through political decision-making) and dialogue' are aimed at as many human beings as possible. There is one condition for the actual success of this ecodomic public theology of nature: to move beyond the present (with its generation) into the near and the distant future (with all subsequent generations) or, in the words of Pearson (2019:98), to accept that such a public theology has a 'demanding intergenerational vocation'.

\section{Theology and nature in mainline Protestantism}

If Eastern Orthodoxy and Roman Catholicism have the same global hierarchy and belief system, mainline Protestantism is much more diverse in this respect, which makes the process of selecting one document as representative for the whole Protestant confessional spectrum a rather difficult task. Nevertheless, for the purposes of this endeavour, Conradie's (2006) Christianity and Ecological Theology appears to be a suitable choice, not only because of Conradie's vast publication record in the field of ecology, but also because he explains ecological concerns through the lens of Protestant theology with a very consistent segment dedicated to practical applications. Conradie's theology is not idle talk about ecological issues and the general relationship between theology and nature but critical engagement and a plethora of solutions as to how Christian theology - confessionally Protestant in doctrine and practice - can appropriate ecological realities as practically as possible (Conradie 2006). According to Conradie, Christian theology must develop not only a set of doctrines that are inclusive of ecological issues but also a practical ministry and spirituality along the same lines. Christopher Southgate notices that, in Conradie, ecology begins with 'the importance of doctrinal ... keys' based on 'biblical interpretation' as 'hermeneutical task'; in other words, Conradie has a 'programme for ecological biblical interpretation' (Southgate 2010:245). As part of it, the first practical aspect of Christian ministry and spirituality which must be correlated with ecology is the liturgy. In this particular respect, Conradie (2006) suggests that ecological issues can be revealed within a large spectrum of liturgical aspects, such as:

$[D]$ oxology, worship, preaching, hymns, prayer, the reading of the law, the sacraments (especially the Eucharist and baptism), penitence, a confession of Christian faith and a confession of guilt, testimonies, Christian architecture, and art (e.g. icons). (p. 85)

It is clear that Conradie's (2006) list can be applied beyond the confessional boundaries of Protestantism, especially because he refers not only to the two Protestant sacraments of the Eucharist and baptism, but also the Christian art as manifested in the painting of icons. Quite obviously, the list is not exhaustive, but it provides a list of possible liturgical aspects which can shed light on ecological matters in a practical, specifically ecclesiological, way. Liturgy, however, is not enough to raise awareness without what Conradie calls 'Christian formation and education'. Thus, ecological issues should be 'included in children's education, catechism, and the curricula of Christian ethics in schools and universities' (Conradie 2006:186). In order for theology and nature to be correlated in a sustainable pattern, education is vital in creating a 'philosophy, goals, basic values' which are aware of ecological concerns (Conradie 2006:186). In this respect, Sewpaul \& Larsen (2014:231) confirm that, in Conradie, 'contextual features ... influence meanings attached to participation and its substantive operationalization' or, put simply, without a common and cohesive plan, action is never going to happen. This is why Conradie (2006:186) emphasises that ideally these theoretical aspects should be supplemented by the actual transformation of 'the physical structure of the institutions where Christianity is being taught' with the specific purpose of creating a sustainable 'ecological vision' capable of producing concrete practical results. The church's work, however, does not end here because its daily pastoral care should and could also be permeated by ecological concerns. Concretely, 'parenting, teaching, counselling, and holistic healing' should be adapted to include 'ecological notions' aimed at 'caring for the Earth' (Conradie 2006:186). Conradie (2006:187) even suggests that caring for the Earth can lead to the actual healing of the human beings engaged in it, so this 'ecotherapy' should become a form of 'Earth ministry'.

Although he does not say it specifically, if ecotherapy really works in its capacity as Earth ministry, it is because Earth is God's creation and caring for God's creation is traditionally supposed to include a deep personal and communitarian faith in God as the creator. If this is the reasoning behind Conradie's proposal, then it is obvious why this effort should prolong itself into an ecologically informed 'Christian witness and mission' (Conradie 2006:187). As far as he is concerned, 'an adequate theology of mission therefore has to include an ecological dimension' predominantly because 'mission may be regarded as a way of proclaiming and establishing God's justice towards the whole cosmos' (Conradie 2006:187). If so, it is not only Earth that should be our specific concern, but also the whole universe as God's creation, although - one must admit - caring even for the former has always been a huge challenge for the human race, let alone the latter. This is why Marais (2018:132) underlines that, according to Conradie, nothing will eventually be done without 'environmental justice' or 'ecojustice' as foundational for an ecological ethics of action. Nevertheless, what really matters in Conradie's argument is the need for 'an ecological spirituality', which, he suggests, should be approached as 'mystic experience' (Conradie 2006:187). In other words, we must see God in nature because God is not only its creator but also its sustainer. This is why Conradie (2006) emphatically states that:

[T] he Christian church has to acknowledge God's presence in the grandeur of nature, in the order of creation, in the cultural achievements of human beings, in human reason, in the moral consciousness present in other religious traditions and in history in general. (p. 188) 
Whether this takes the form of a certain 'natural theology' which sees nature as a 'vehicle to experience God's presence' is not important for as long as caring for nature becomes a 'mystical experience', which leads to concrete change in the practical reality of the world. Conradie is a Protestant but he underlines that his proposal is not limited to Protestantism. As such, he clearly explains that such practical changes are based on 'spiritualities' which although 'often follow the confessional distinctions between the Orthodox, Catholic, Lutheran, Reformed, Anabaptist, and Pentecostal traditions within Christianity' can become 'transconfessional theological movements' because they 'provide access to God's presence in nature' (Conradie 2006:189). Conradie's awareness of the reality of nature allows him to include references to ecofeminist and ecowomanist spiritualities which are supposed to facilitate human connections with nature because of 'women's more immediate and organic access to cycles of fertility' (Conradie 2006:189). At this point, it is important to understand that, as explained by Edwards (2009:86), Conradie builds his ecotheology 'on the transcendence and otherness of God', which 'enables God to be present creatively to each creature' and is the traditional approach to God in confessional theologies. However, even if he speaks about specifically Christian spiritualities, Conradie realises that without interreligious dialogue and the involvement of people belonging to all religious traditions, ecological concerns will forever remain theoretical and devoid of practical implementation. Consequently, he speaks about 'the ecological need for religious wisdom' without which ecology is literally doomed (Conradie 2006:190). In order to avoid this real possibility, theology, education and religion must be in conversation with politics. For Conradie, politics is vital because it has capacity to find a common course of action by moving beyond 'the tensions between the North and the South, between the First and the Third World, between industrialized and developing countries, between economic centres and peripheries' (Conradie 2006:20-21).

Conradie's position is profoundly ecodomic because it puts together theology, religion, education and politics in an effort to counter the destructive consequences of industrialisation on nature. As Herron (2010:109) notices, it may be the case that our societies need 'an infusion of nature's purity' for the sake of restoring our 'spiritual compass' and this is exactly what Conradie is doing in raising awareness of ecological concerns and then trying to address them as practically as possible. Conradie's work is also an excellent sample of public theology because his proposal is not limited only to the churches but is meant to be appropriated by any other institution or person, irrespective of one's theological, religious or political convictions. This realisation is crucial because, according to Conradie, the world is seen not only as God's creation but also what Scott (2003:30) calls 'the common realm of God, nature, and humanity'. Regardless of whether one sees human beings as created by God or not, the fact is that all human beings live in the same world and share the same resources, which is a clear indication that if global problems are to be solved, then working solutions must be found across theologies, religions, economies, and educational and political systems. In other words, and this is what Conradie's vision is all about, we should better solve our problems because nobody is going to fix them for us.

\section{Moving from confessional theologies towards secular philosophies (and back?)}

Regardless of whether they are Eastern Orthodox, Roman Catholic or mainline Protestant, confessional theologies about the state of nature and the environment have three main aspects in common: education, economy and politics. When these three are put together in a theological discourse, the result is a public theology of nature which is essentially ecodomic in nature. At this stage, however, it is important to see whether such an ecodomic public theology defined by education, economy and politics has these three specific elements in common with a generally secular philosophy devoid of theological agendas. In order to see if this comparison works in reality, two documents were selected for this purpose: firstly, the so-called 'Accra Confession', drafted and published in 2004 by the World Alliance of Reformed Churches, a theological document which represents confessional theologies (WCC 2004), and, secondly, the 'Earth Charter', published in 2004 by the Earth Charter (2000) Commission in conjunction with Queen Beatrix of the Netherlands, an ethical document which represents secular philosophies. By comparing these two key documents dealing with ecological issues, it is important to establish not only if they contain the same emphasis on education, economy and politics but also if there such emphases allow for some common ground between confessional theologies and secular philosophies about ecology and nature in spite of their opposing frameworks (confessional theologies believe in an ontologically real God whilst secular philosophies do not). In other words, it is crucial to establish if Christians can move beyond their own confessional theologies about nature in accepting the role of secular philosophies about nature and, at the same time, if non-Christians and non-religious people can follow the same pattern in conceding that Christian confessional theologies about nature can be constructive and useful with regard to our common understanding of nature.

The 'Accra Confession' is openly theological because it affirms the ontologically real presence of God as the 'creator and sustainer of all life' as well as 'sovereign over creation', in which capacities he 'made a covenant with all creation' (WCC 2004:3). This state of affairs, however, is no longer in place today because the current situation of nature and the environment is presented in gloomy terms as defined by 'climate change, depletion of fish stocks, deforestation, soil erosion, and threats to fresh water' - all labelled as 'devastating consequences' of bad economic policies implemented by 'industrialized countries' and the 'drive 
for profit of transnational corporations' (WCC 2004:1). Thus, in light of the contemporary 'oppression of the global economic system' and the 'global economic injustice' leading to 'ecological destruction' by plundering the Earth (WCC 2004:1), the 'Accra Confession' establishes the need for better and safer economic policies throughout the world. Good economies are vital for the state of nature because 'economic systems are a matter of life and death' (WCC 2004:1). Economies should not defend the strong and powerful, but seek to improve the life of everybody, including the weak and the disenfranchised. In other words, economies must 'sustain life' and in doing so be 'accountable to God' in a 'just relationship with all creation' (WCC 2004:3). Such a global awareness cannot be achieved without education, which must be deepened and implemented by action (WCC 2004:4). Also, education cannot be performed without good politics - not the sort which supports the rich and powerful, but the good kind which protects life in all its forms and does justice to everybody (WCC 2004:2). In emphasising the mandatory character of justice, the 'Accra Confession' builds on the legacy and vision of the World Council of Churches, which insists on the need that all aspects of life, including economy, ethics and ecology should be permeated by justice (WCC n.d.). As Pillay (2018:5) explains in one of his recent articles, the reality of justice is of critical importance for the 'Accra Confession', because without justice the 'very integrity of the Gospel' is endangered. The 'Accra Confession' therefore promotes the necessity of good economies, education and politics for the defence of nature and the environment, in which case its theology is not only public in scope but also ecodomic in nature as it addresses everybody in a constructive manner.

Written from a totally different and opposing perspective, the 'Earth Charter' is a secular document which recognises the state of nature in terms that present an accurate image of planet Earth's contemporary state of affairs: Earth is defined as 'our home', its current 'global situation' is defined by 'injustice, poverty, ignorance, and violent conflict', which emphasises the need for 'fundamental changes' in 'our values, institutions, and ways of life', a task that cannot be accomplished without 'universal responsibility' (The Earth Charter 2000:1). The charter attempts to raise awareness regarding the urgent need to promote social and economic justice because, as it stands nowadays, the world is devoid of such realities. Concretely, the charter indicates that economic activities must be performed in such a way that poverty is eradicated and 'human development' is promoted 'in an equitable and sustainable manner'. Ambitious as they are, these purposes are meant to create economies based on creating opportunities 'without discrimination', which are 'supportive of human dignity, bodily health, and spiritual well-being' (The Earth Charter 2000:3). Such economies must also actively promote education, without which the sustainability of these economies is not only difficult to envisage but also impossible to maintain. Education itself must be defined by 'access to education', in which case it must be made available to as many people as possible at a global scale (The Earth Charter 2000:3). Serious action must be taken in this respect regardless of whether 'formal education' or 'life-long learning' is concerned; what matters, however, is that - in all its forms - education must 'integrate ... knowledge, values, and skills needed for a sustainable way of life' (The Earth Charter 2000:4). In this sense, education must be both 'moral and spiritual' (The Earth Charter 2000:4). This specific kind of education cannot be conceived and implemented without realising that today's challenges are not only 'environmental, economic, social, and spiritual' but also 'political' (The Earth Charter 2000:1). Neither the economy nor the education envisaged in the charter can be achieved without 'active participation' in 'political life' of as many people as possible in their capacities as 'equal partners, decision makers, leaders, and beneficiaries' (The Earth Charter 2000:2). It is safer to assume, therefore, that the 'Earth Charter' promotes a secular philosophy which insists on the need to promote better economies, better education and better politics if the current state of nature and the environment, which is seriously afflicted by human activities, stands a chance to be rectified in the future.

Provided that despite their opposing nature, both the 'Accra Confession' and the 'Earth Charter' are deeply concerned with a theoretical framework aiming at the implementation of proper economies, education and politics for the sake of nature and the environment, it is quite safer to assume that moving from confessional theologies to secular philosophies is not only possible but also necessary in contemporary societies. People across the world, Christians and nonChristians, religious and non-religious, theistic and atheistic, have at least some form of spirituality which is informed morally and performed culturally in societies that exist on the same planet, in the same world, within the same environment. Thus, moving from confessional theologies as expressed in the 'Accra Confession' towards secular philosophies as captured by the 'Earth Charter' should not be exclusively a one-way journey. On the contrary, the other movement - from secular philosophies to confessional theologies - must remain open at least for those who are interested in taking this route. Why? Because both confessional theologies and secular philosophies about nature can be perceived as public cultural (ethical) enterprises with clearly defined ecodomic (or constructive) goals despite their mutual opposition. For the purposes of living together, however, in the same world, on the same Earth seen as 'our home', with a quality of life which is better and better by the day, the cultural, economic, educational and political symbiosis of confessional theologies and secular philosophies about nature and the environment is mandatory without equivocation. Still, joining two opposing belief systems can produce friction and conflict even if common ground is to be found in both. This is why a new proposal may be perhaps an even better solution. 


\section{Concluding Remarks: Towards an ecodomic public attitude about nature}

It is clear that confessional theologies and secular philosophies have in common only the same concern for the world as cradle of all life; in any other respects, they are opposed to each other, especially in accepting God's existence as ontologically real (which is foundational for confessional theologies and indifferent, if not repulsive to secular philosophies). But because they share the same preoccupation about the world, the state of the world as nature is an issue which cannot be detached from either confessional theologies or secular philosophies. Irrespective of the fact that confessional theologies accept the idea of an ontologically real God who created nature whilst secular philosophies reject it, it is indisputable that nature itself is the common denominator of both endeavours. Thus, they are both preoccupied with economy, education, and politics and in doing so they both address the public square in all its cultural complexity. Because the intention behind both is the improvement of the current state of nature, finding a distinctively common interest in both is not difficult despite their being fundamentally opposed in their specific methodologies. So it seems that, in putting them together based on their common interest in nature (although from different and opposing perspectives), it is necessary to move beyond both towards a new approach, which can be neutrally called 'attitude' (something which is neither a theology, nor a philosophy but includes their common focus). Both Christians and non-Christians, religious and non-religious people, as well as virtually any other group of people inspired by a certain cultural agenda can find it within themselves to work together for the improvement of nature and the environment. If for Christians nature is divine in its capacity as God's creation, for secular people nature is the context of life; either way, neither group denies its importance, and both admit that doing something about it is what truly matters. Nevertheless, doing something means more than just talking about it; finding solutions and then actively implementing them is mandatory for the situation to change for the better. After all, all human beings share the same planet, the same resources, and the same reality; we all breathe the same air, as it were, and it is exclusively up to us if what gets into our lungs is clean or not.

From the perspective of confessional theologies, being interested in nature in order to change the situation of economic, educational, and political systems for the improvement of nature in general is proposing an ecodomic public attitude about nature which goes beyond both confessional theologies and secular philosophies. Such an attitude can easily be accepted by secular people but just in case some are not happy about this ecodomic public theology of nature, another solution is at hand: and this resides in combining the idea of 'confessional theology' with that of 'secular philosophy'. The result would be a 'secular theology' and a 'confessional philosophy' whose common ground should be easier to circumscribe. As Clayton Crockett (2001:1) suggests, secular theology should be preoccupied not only with the sacred but also with the secular, or with what happens in the world, which is exactly what confessional theologies do. On the other hand, confessional philosophy should invest itself into what Roger Ward calls human transformation, notably the transformation of character (Ward 2018:chapter 4), an aspect which secular philosophies do attempt to achieve by changing societal perspectives on human values. Regardless of whether one may or may not be willing to accept constructs such as 'confessional theology' and 'secular philosophy' or 'secular theology' and 'confessional philosophy', any enterprise which is aimed at improving the current state of nature and the environment must be ecodomic and public - and it can be so if one succeeds in moving beyond any traditional and opposing patterns of thought into this common public attitude about nature, which is actively and permanently constructive. In other words, the solution can be such an ecodomic public attitude about nature, designed to assist contemporary people in not only talking about but also acting upon feasible solutions for the betterment of nature.

\section{Acknowledgements}

This research is part of my Senior Vice-Chancellor Postdoctoral Research Fellowship at the Faculty of Theology and Religion within the University of Pretoria, under the supervision of Professor Johan Buitendag.

\section{Competing interests}

The author declares that he has no financial or personal relationships that may have inappropriately influenced him in writing this research article.

\section{Author's contributions}

C.C.S. is the sole author of this research article.

\section{Ethical considerations}

This article followed all ethical standards for a research without direct contact with human or animal subjects.

\section{Funding informations}

The research received no specific grant from any funding agency in the public, commercial or not-for-profit sectors.

\section{Data availability statement}

Data sharing is not applicable to this article as no new data were created or analysed in this study.

\section{Disclaimer}

The views and opinions expressed in this article are those of the author and do not necessarily reflect the official policy or position of any affiliated agency of the author. 


\section{References}

Balabanski, V.S., 2020, Colossians - An Earth Bible commentary: An eco-stoic reading T\&T Clark, London.

Buitendag, J., 2019, 'Some reflections on the genealogy of the 'Pretoria model': Towards a definition of theological education at a public university', HTS Teologiese Studies/Theological Studies 75(3), a5487. https://doi.org/10.4102/ Teologiese Studies
hts.v75i3.5487

Chryssavgis, J., 2013, 'A new heaven and a new Earth: Orthodox Christian insights from theology, spirituality, and the sacraments', in J. Chryssavgis \& B.V. Foltz (eds.), Toward and ecology of transfiguration: Orthodox Christian perspectives on environment, and ecology of transfiguration: Orthodox Christian perspectives on environ
nature, and creation, pp. 152-162, Fordham University Press, New York, NY.

Clapsis, E., 2020, 'The great and holy council of the orthodox churches in the public sphere', in G. Giordan \& S. Zrinščak (eds.), Global Eastern Orthodoxy. Politics, religion, and human rights, pp. 77-100, Springer, Cham.

Conradie, E., 2006, Christianity and ecological theology: Resources for further research, African Sun Media and Stellenbosch University, Stellenbosch.

Crockett, C., 2001, 'Introduction', in C. Crocket (ed.), Secular theology: American radical theological thought, pp. 1-9, Routledge, London.

Dimitrios, 1989, Message by H.A.H. ecumenical patriarch Dimitrios upon the day of prayer for the protection of creation (September 1st, 1989), viewed 09 March 2020, from
https://www.patriarchate.org/-/message-by-h-a-h-ecumenical-patriarch-dimitrioshttps://www.patriarchate.org/-/message-by-h-a-h-ecumenical-p
upon-the-day-of-prayer-for-the-protection-of-creation-01-09-1989-

Edwards, D., 2009, 'Ecotheology', in H.A. Campbell \& H. Looy (eds.), A science and religion primer, pp. 85-87, Baker Academic, Grand Rapids, MI.

Francis, 2015, Encyclical letter Laudato Si' of the Holy Father Francis on care for our common home, viewed 10 March 2020, from http://www.vatican.va/content/ francesco/en/encyclicals/documents/papa-francesco_20150524_enciclicalaudato-si.html.

Francis of Assisi, 1999, 'Canticle of creatures', in Francis of Assisi: Early documents, vol. 1, pp. 113-114, Franciscan Institute of St. Bonaventure University, New York, NY.

Herron, J.P., 2010, Science and social good: Nature, culture, and community, 1865-1965, Oxford University Press, Oxford.

Kerber, G., 2020, 'A response to Wesley Granberg-Michaelson', in E.M. Conradie \& H.P. Koster (eds.), T\&T Clark Handbook of Christian Theology and Climate Change, pp. 351-358, T\&T Clark, London.

Kim, S.C.H., 2011, Theology in the public sphere, SCM Press, London.

Kinnamon, M., 2014, Can a renewal movement be renewed? Questions for the future of ecumenism, Eerdmans, Grand Rapids, MI.
Kureethadam, J.I., 2019, The ten green commandments of Laudato Si', Liturgical Press, Collegeville, MN.

Marais, N., 2018, 'Blue is the warmest colour: Theology, ethics, water', in C. Jones (ed.), Justice-based ethics: Challenging South African perspectives, pp. 121-142, AOSIS, Cape Town.

Müller-Fahrenholz, G., 1995, God's Spirit: Transforming a world in crisis, World Council of Churches/Continuum, New York, NY.

Nellist, C., 2018, Eastern orthodox Christianity and animal suffering: Ancient voices in modern theology, Cambridge Scholars Publishing, Newcastle upon Tyne.

Pearson, C., 2019, 'Acting justly in the anthropocene: Considering the case for a Christian social ethic', in C. Pearson (ed.), Enacting a public theology, pp. 87-98, African Sun Media and Stellenbosch University, Stellenbosch.

Pillay, J., 2018, 'The Accra Confession as a response to empire', HTS Teologiese Studies/ Theological Studies 74(4), a5284. https://doi.org/10.4102/hts.v74i4.5284

Prellwitz, J.H., 2017, “'Laudato Si," communication ethics, and the common good: Toward a dialogic meeting amid environmental crisis', Journal of Moral Theology 6(1), 144-158

Rourke, T.R., 2016, The roots of Pope Francis's social and political thought: From Argentina to the Vatican, Rowman and Littlefield, Lanham, MD.

Sagovsky, N., 2017, 'Public theology, the public sphere, and the struggle for social justice', in S.C.H. Kim (ed.), A companion to public theology, pp. 251-270, Brill, Leiden.

Scott, P., 2003, A political theology of nature, Cambridge University Press, Cambridge.

Sewpaul, V. \& Larsen, A.K., 2014, 'Community development: Towards an integrated emancipatory framework', in A.K. Larsen, V. Sewpaul \& G.O. Hole (eds.), Participation in community work: International perspectives, pp. 230-246, Routledge, London.

Southgate, C., 2010, 'Introduction', in D.G. Horrell, C. Hunt, C. Southgate \& F. Stavrakopoulou (eds.), Ecological hermeneutics: Biblical, historical, and theological perspectives, pp. 243-245, T\&T Clark, London.

Ward, R., 2018, Peirce and religion: Knowledge, transformation, and the reality of God, Lexington Books, Lanham.

The Earth Charter, 2000, The Earth Charter, viewed 12 March 2020, from https:// earthcharter.org/discover/the-earth-charter/.

WARC, 2004, The Accra Confession, viewed 12 March 2020, from http://wcrc.ch/ accra/the-accra-confession.

World Council of Churches, n.d., What we do, viewed 10 February 2020, from https:// www.oikoumene.org/en/what-we-do/eco-justice. 